\title{
Detection of predation on Euzophera pingüis (Lepidoptera: Pyralidae) using an enzyme-linked immunosorbent assay
}

\author{
Estefanía RODRÍGUEZ, Carlos LOZANO and MERCEdes CAMPOS
}

\begin{abstract}
Department of Agroecology and Plant Protection, Estación Experimental del Zaidín (CSIC), Profesor Albareda 1, 18008 Granada, Spain; e-mail: estefania.rodriguez@eez.csic.es, mcampos@eez.csic.es
\end{abstract}

Key words. Lepidoptera, Pyralidae, olive, serological bioassay, predators

\begin{abstract}
Euzophera pingüis (Lepidoptera: Pyralidae) is a secondary olive pest, which has increased in importance during recent years. In this study, more than 1300 predatory arthropods were collected from a Spanish olive orchard over two years and assayed using a pest-specific ELISA. Abundance and the percentage of positive responses to E. pingüis obtained using ELISA showed spiders to be the main predator, especially in 1998, when they accounted for $18 \%$ of the predation, followed by Scymnus suturalis (Coleoptera: Coccinellidae) and Brachinotocoris ferreri (Heteroptera: Miridae). Neuroptera and ants were less important as predators of E. pingüis.
\end{abstract}

\section{INTRODUCTION}

Euzophera pingüis Haworth (Lepidoptera: Pyralidae) is a secondary pest of olive trees (Olea europaea) and attacks various Oleaceae in several parts of northern and central Europe. This species is most common in the Mediterranean olive-growing regions and north Africa (Lousert \& Brousse, 1980; Claridge \& Walton, 1992; Durán et al. 1998). Its importance has increased recently due to inadequate crop management and excessive use of insecticides (Bueno, 1995; Celada, 2001; Sanchez \& Ortiz, 2004). E. pingüis has two generations per year; the adults emerge from April to June and from August to October, mate and oviposit. Their larvae excavate galleries under the bark causing the interruption of sap flow, death of branches and even death of immature trees (De Andrés, 1991).

Cultural and insecticide-based pest management are the suggested methods of control (Alvarado, 1998; Durán et al., 1998; Civantos, 1999; Rodríguez \& Campos, 2004). However, due to the ecological and health-related problems of insecticide application, alternative systems based on semiochemicals have been recommended (Ortiz, 1996; Oliveros et al., 2003; Sanchez \& Ortiz, 2004). The natural enemies, two braconids [Iconella myelolenta and Phanerotoma ocularis (Hymenoptera, Braconidae)] have some impact on E. pingüis populations (Alvarado, 1998; Durán et al., 1998). However, there is no literature on the potential predators of this pest.

Serological tests, such as the enzyme-linked immunosorbent assay (ELISA), provide a method of detecting predation without disrupting the environment (Greenstone, 1996), as it can be used to rapidly identify the remains of prey in the alimentary canal of predators (Sunderland \& Sutton, 1980; Kapuge et al., 1987; Hagler \& Naranjo, 1994; Symondson et al., 1996). It is even possible to quantify the amount of prey consumed (Naranjo \& Hagler, 2001). In olive orchards, predators of Prays oleae (Lepidoptera: Plutellidae), one of the principal pests of this crop, have been identified using this technique (Morris et al., 1999a).

The aim of the present work is to identify the predators of $E$. pingüis using ELISA, a preliminary step in the biological control of this insect.

\section{MATERIAL AND METHODS}

Study site

All field sampling was done in a commercial olive orchard (Picual variety) close to Córdoba (eastern Andalusia, southern
Spain) over a period of two years. The orchard covered 200 ha, had 10 to 30 year old trees planted at intervals of $10 \times 10 \mathrm{~m}$. According to the farmer dimethoate and alpha-cypermetrin sprays against the pest Prays oleae and soil treatment with the herbicide simazine were applied.

\section{Predator sampling}

Predators were collected from 20 randomly selected trees every 15 days in spring and autumn, coinciding with the two generations of the pest (Civantos, 1999). Each tree was shaken five times at the same height $(1.5 \mathrm{~m})$ at the four cardinal points. Arthropods dislodged by the shaking fell directly into a plastic bug, which could be folded, to prevent mobile predators from escaping. The labelled samples were taken to the laboratory and stored at $-20^{\circ} \mathrm{C}$ prior to counting, identification and using assays to detect the presence of E. pingüis proteins. In 1997, the flight period of $E$. pingüis adults lasted from mid-April to mid-May and from mid-September to mid-November. In 1998, the adult flight period spanned March to July. During the second generation of the pest the number of predators captured was low (total $<20$ ) and no positives were registered, so this data is not presented.

\section{Testing for predation}

Preparation of antiserum

The specific antiserum was developed by Lozano et al. (1999) by immunizing a rabbit, previously bled to obtain the normal rabbit serum for baseline comparisons. The rabbit received two multi-site intradermal injections of $1 \mathrm{ml}$ of $50: 50$ solution of a whole homogenate of E. pingüis larvae with Freund's complete adjuvant, four weeks apart, and then one week later was bled from a marginal ear vein. A second batch of antiserum was obtained after a third boost one month later. The antiserum was extracted from the blood of the rabbit by coagulation and centrifugation and stored at $-20^{\circ} \mathrm{C}$ until used to detect $E$. pingüis proteins. To protect against cross-reactions Lozano et al. (1999) applied the antiserum to 27 different arthropod species. All predators tested with the polyclonal antiserum which gave a calculated concentration equivalent (CE) greater than 2.0, the mean $\mathrm{CE}$ for the highest cross-reacting species (Prays oleae) plus 2.5 S.D., were considered positive sensu Symondson \& Liddell (1993a). 
TABLE 1. Number of predators tested by ELISA in 1997 and 1998, and the percentage of positive reactions for the pest Euzophera pingüis recorded.

\begin{tabular}{|c|c|c|c|c|}
\hline \multirow{3}{*}{ Date } & \multicolumn{4}{|c|}{ YEAR } \\
\hline & \multicolumn{2}{|c|}{1997} & \multicolumn{2}{|c|}{1998} \\
\hline & Individuals & $\%$ Positive & Individuals & \% Positive \\
\hline 15 April & $*$ & $*$ & 31 & 19.4 \\
\hline 30 April & 51 & 0 & 19 & 0 \\
\hline 15 May & 305 & 0.7 & 7 & 14.3 \\
\hline 30 May & 346 & 0 & 22 & 9.1 \\
\hline 15 June & $*$ & $*$ & 47 & 17.0 \\
\hline 30 June & * & $*$ & 71 & 0 \\
\hline 15 July & $*$ & $*$ & 46 & 17.4 \\
\hline 30 July & $*$ & $*$ & 11 & 9.1 \\
\hline 15 October & 129 & 3.9 & $*$ & $*$ \\
\hline 30 October & 59 & 5.1 & $*$ & $*$ \\
\hline 15 November & 39 & 7.7 & $*$ & $*$ \\
\hline 30 November & 98 & 2.0 & $*$ & $*$ \\
\hline TOTAL & 1027 & 1.5 & 254 & 10.2 \\
\hline
\end{tabular}

* Not sampled

Preparation of predator's homogenate

All predators were weighed and stock solutions made in PBS tablet (10mM phosphate buffer, $\mathrm{pH} 7.4,150 \mathrm{mM} \mathrm{Na} \mathrm{Cl})$. The stock solutions were $1: 2,1: 20,1: 200(\mathrm{w} / \mathrm{v})$ depending on the weight. Using disposable pellet pestles (Kontes Glass Co.
USA), each specimen was macerated individually in an eppendorf tube and the resultant homogenate centrifuged at 10,000 rpm for $15 \mathrm{~min}$. The supernatant was then collected, labelled and stored at $-20^{\circ} \mathrm{C}$ for subsequent assay.

The immunoassay used was the indirect ELISA, performed in 96-well microtitration plates (Greiner, Germany) following the protocol described by Symondson et al. (1996). A goat antirabbit IgG conjugate with horseradish peroxidase was used, with orthophenylenediamine in a citrate-phosphate buffer as the enzyme substrate. Each plate was calibrated using an $E$. pingüis dilution series obtained from a $1: 20000(\mathrm{w} / \mathrm{v})$ solution.

\section{Statistical analysis}

The proportions of positives in the two years were compared using a $\chi^{2}$-test.

\section{RESULTS AND DISCUSSION}

\section{Predator population}

During the two generations of E. pingüis, the total number of predators captured in 1997 was approximately four times that in 1998 (Tables 1, 2), probably due to the low temperatures recorded in 1998. Other studies also note similar differences in the year to year catches of predators in olive orchards, depending on climatic conditions. (Belcari \& Dagnino, 1995; Morris et al., 1999b).

In both years of the study, the most abundant groups were Coleoptera, Araneae, Heteroptera and ants (Table 2).

Two species of Heteroptera, Brachinotocoris ferreri and Phytocoris oleae (Miridae) were caught. The species Scymnus suturalis represented $98.7 \%$ of all the Coleoptera caught, but was

TABLE 2. Total number of the different predators collected from olive trees. In brakets are shown the percentage scored positive for the presence of Euzophera pingüis proteins. SAS: Mean of ELISA DO values for the specific antiserum absorbed in the positive responses.

\begin{tabular}{|c|c|c|c|c|}
\hline \multirow{3}{*}{ Groups } & \multicolumn{4}{|c|}{ YEAR } \\
\hline & \multicolumn{2}{|l|}{1997} & \multicolumn{2}{|c|}{1998} \\
\hline & total tested (\% positive) & SAS & total tested (\% positive) & SAS \\
\hline \multicolumn{5}{|l|}{ HYMENOPTERA } \\
\hline Formicidae & $200(0.0) \mathrm{a}$ & $0.0 \pm 0.0$ & $32(3.1) \mathrm{b}$ & $0.801 \pm 0.0$ \\
\hline \multicolumn{5}{|l|}{ NEUROPTERA } \\
\hline Chrysopidae & $43(2.3)$ & $0.651 \pm 0.0$ & $51(5.9)$ & $1.135 \pm 0.045$ \\
\hline COLEOPTERA & $402(2.3)$ & & $10(10.0)$ & \\
\hline Coccinellidae & $376(2.4)$ & $0.982 \pm 0.392$ & $8(12.5)$ & $0.800 \pm 0.0$ \\
\hline Carabidae & $9(0.0)$ & & $0(0.0)$ & \\
\hline Cybocefalidae & $10(0.0)$ & & $0(0.0)$ & \\
\hline Staphylinidae & $7(0.0)$ & & $2(0.0)$ & \\
\hline HETEROPTERA & $86(3.5)$ & & $114(7.9)$ & \\
\hline Miridae & $75(1.3)$ & $0.540 \pm 0.0$ & $97(8.2)$ & $1.123 \pm 0.309$ \\
\hline Anthocoridae & $6(0.0)$ & & $16(0.0)$ & \\
\hline Pentatomidae & $5(40)$ & $1.012 \pm 0.324$ & $1(100)$ & $0.837 \pm 0.0$ \\
\hline ARANEAE & $278(0.8) \mathrm{a}$ & & $65(18.5) \mathrm{b}$ & \\
\hline Salticidae & $27(0.0)$ & & $4(0.0)$ & \\
\hline Thomisidae & $35(0.0)$ & & $30(33.3)$ & $0.80 \pm 0.158$ \\
\hline Clubionidae & $27(3.7)$ & $1.589 \pm 0.0$ & $1(0)$ & \\
\hline Others & $189(0.5)$ & $0.525 \pm 0.0$ & $30(6.7)$ & $0.739 \pm 0.074$ \\
\hline \multicolumn{5}{|l|}{ OTHERS } \\
\hline Forficulidae & $9(0.0)$ & & $3(0.0)$ & \\
\hline Mantidae & $9(0.0)$ & & $0(0.0)$ & \\
\hline TOTAL & $1027(1.5) \mathrm{a}$ & & $275(9.5) b$ & \\
\hline
\end{tabular}

Different letters within the same row indicate significantly different percentages of positives at $P<0.05$ ( $\chi^{2}$-test). 
scarcer in the second year of the study. Neuroptera were represented exclusively by the family Chrysopidae, with two species: Chrysoperla carnea and Mallada sp. The latter comprised 88\% of the captures. Ants were one of the most abundant groups in 1997 (Table 2), with three species represented, Lasius niger, Tapinoma nigerrimum and Camponotus lateralis (the last was scarce and occasional).

\section{Testing for predation}

In 1997, positive reactions were obtained in spring for predators collected on only one date, 15 May. In autumn, the percentage of positives increased to a maximum on 15 November. In 1998, more positives were obtained throughout the season, without any discernible pattern (Table 1). The higher predation in 1998 was probably due to the longer oviposition and developmental periods of the pest, which prolonged its exposure to predators. Our antiserum did not distinguish the developmental stage eaten, but given the dates on which the positives were obtained, it is likely to have been the early stages of development; eggs and young larvae. The eggs and young larvae are the most vulnerable because they are present on the bark of the trees. Later the larvae penetrate the bark and make subcortical galleries in which they pupate (Civantos, 1999).

In 1998, the highest percentage of positives was found for spiders, followed by Coleoptera, Heteroptera and Neuroptera (Table 2). By contrast, Morris et al. (1999a), also using ELISA, identified ants as the most abundant and important predators of Prays oleae and Coleoptera, Heteroptera and spiders as relatively minor predators of this pest (Morris et al., 1999a).

In 1998 , predation by spiders exceeded $18 \%$, and the family with the greatest effect on E. pingüis was the Thomisidae, with 10 out of 30 individuals positive. These predators ambush their prey and thus it is possible that they attacked neonate larvae as they began to excavate their galleries or females looking for suitable oviposition sites. Some clubionids tested positive, as did some of the spiders in the group "other spiders", while no positives were recorded for the salticids.

The highest number of Heteroptera collected and of positive reactions coincided with the first generation of the pest. The most effective predator was $B$. ferreri, both in terms of its abundance and positive reactions. This species fed on the pest as early as 15 April. Only two positives were recorded for Phytocoris oleae, one on 15 May 1997 and the other on 15 June 1998. No positive reaction was recorded for Anthocoris nemoralis possibly because this predator grows and reproduces best on a diet of psyllids and aphids (Drukker et al., 2000).

Of the beetles (Coleoptera), only positive ELISA responses were recorded for ladybirds (Coccinelidae) and of these Scymnus suturalis accounted for 93\% in 1997 and 70\% in 1998. In the first year, predation by beetles was only recorded in the second generation of $E$. pingüis (October to November). In 1998, only one positive was recorded and that was for Coccinella septempunctata.

Several authors (Sunderland \& Sutton, 1980; Sunderland et al., 1987; Du Devoir \& Reeves, 1991) indicate that the most abundant predator is not always the most effective predator of the target prey. In our case, the highest percentage of positives was not recorded for the most abundant group of predators. This aspect should be considered when developing an integrated pest management programme, in which insecticide use is often determined by the sensitivity of the most abundant predator (Greenstone, 1996).

In addition, interpreting the results of ELISA is complex, particularly when comparisons are made across groups or between years. Various factors should be considered (Morris et al., 1999a), including meal size, mixed feeding and hunger level
(Lövei et al., 1985, 1987, 1990), time that has elapsed since consumption (Symondson \& Liddell, 1993a), temperature (Hagler \& Cohen, 1990) and the species in question (Symondson \& Liddell, 1993b). In 1998, the highest number of positives was recorded for spiders, and this may be due to the slower rate of digestion in these arthropods (Greenstone, 1983; Sunderland et al., 1987). On the other hand, activities such as secondary predation and scavenging can give rise to false positives (Sunderland, 1996). However, this qualitative study gives a rough indication of the more important predator groups and opens new avenues of research for encouraging and managing these potential biological control agents.

ACKNOWLEDGEMENT. We thank P. Vargas, F. Cañete, R. Barrera, M. Cea and H. Barroso for their help at various stages of the work. D. Nesbitt revised the English version of this manuscript. This research was supported by the national research project CAO97-007 funded by Instituto Nacional de Investigaciones Agrarias (INIA).

\section{REFERENCES}

Alvarado M. 1998: Es el olivar un cultivo desequilibrado? Potenciación de otiorrinco (Othiorrynchus cribicollis), gusanos blancos (Melolontha papposa), abichado (Euzophera pingüis), cochinilla (Saissetia oleae) y ácaros (Aceria oleae) en las nuevas plantaciones. Phytoma 102: 116-122.

Belcari A. \& Dagnino A. 1995: Preliminary analysis of the insects caught by a "malaise" trap in an olive grove in northern Tuscany. Agr. Mediterr. 125: 184-192.

Bueno F. 1995: Una plaga en aumento: La piral del olivo (Euzophera pingüis). Agricultura. 62: 860-867.

Celada B. 2001: Lepidópteros xilófagos en las plantaciones de olivo. Agromillora Catal. 4: 23-29.

Civantos M. 1999: Control de Plagas y Enfermedades del Olivar. Consejo Oleícola Internacional, Madrid, $207 \mathrm{pp}$.

Claridge M.F. \& Walton M.P. 1992: The European olive and its pest-management strategies. BCPC Mono. 52: 3-12.

De AndRÉs F. 1991: Enfermedades y Plagas del Olivo. Riquelme and Vargas, S.L. Jaén, Spain, 646 pp.

Drukker B., Bruin J. \& SABelis M.W. 2000: Anthocorid predators learn to associate herbivore-induced plant volatile with presence or absence of prey. Physiol. Entomol. 25: 260-265.

Du Devolr D.S. \& ReEves R.M. 1991: Feeding activity of carabid beetles and spiders on gypsy moth larvae (Lepidoptera: Lymantridae) at high density prey populations. J. Entomol. Sci. 25: 341-354.

Durán J.M., Alvarado M., Serrano A. \& De La Rosa A. 1998: Contribución al conocimiento de Euzophera pingüis (Haworth, [1881]) (Lep: Pyralidae), plaga del olivo. Bol. San. Veg. Plagas 24: 267-278.

GREENSTONE M.H. 1983: Site-specifity and site tenacity in a wolf spider: a serological dietary analysis. Oecologia 56: 79-83.

Greenstone M.H. 1996: Serological analysis of arthropod predation: past, present and future. In Symondson W.O.C. \& Liddell J.E. (eds): The Ecology of Agricultural Pests: Biochemical Approaches. Chapman \& Hall, London, pp. 265-300.

Hagler J.R. \& Cohen A.C. 1990: Effects of time and temperature on digestion of purified antigen by Geocoris punctipes (Hemiptera: Lygaeidae) reared on artificial diet. Ann. Entomol. Soc. Am. 83: 1177-1180.

Hagler J.R. \& Naranjo S.E. 1994: Determining the frequency of heteropteran predation on sweet-potato whitefly and pink bollworm using multiple ELISAs. Entomol. Exp. Appl. 72: 59-67. 
Kapuge S.H., Danthanarayana W. \& Hoogenraad N. 1987: Inmunological investigation of prey-predator relationships for Pieris rapae (L.) (Lepidoptera: Pieridae). Bull. Entomol. Res. 77: $247-254$.

Lousert R. \& Brousse G. 1980: El Olivo. Mundi-Prensa, Madrid, $188 \mathrm{pp}$.

Lövei G.L., Monostroi A. \& Ando I. 1985: Digestion rate in relation to starvation in the larva of a carabid predator, Poecilus cupreus. Entomol. Exp. Appl. 37: 123-127.

LÖVEI G.L., Sopp P. \& Sunderland K.D. 1987: The effect of mixed feeding on the digestion of the carabid Bembidion lampros. Act. Phyt. Entomol. Hung. 22: 403-407.

Lövei G.L., Sopp P. \& SunderLAND K.D. 1990: Digestion rate in relation to alternative feeding in three species of polyphagous predators. Ecol. Entomol. 15: 293-300.

Lozano C., Morris T. \& Campos M. 1999: Development and characterization of a polyclonal antiserum for the detection of predators of Euzophera pingüis (Lep: Pyralidae). Acta Hort. 474: 563-566.

Morris T.I., Campos M., Kidd N.A.C. \& Symondson W.O.C. 1999a: What is consuming Prays oleae (Bernard) (Lep.: Yponomeutidae) and when: a serological solution? Crop Prot. 18: $17-22$.

Morris T.I., CAmpos M., Kidd N.A.C., Jervis M.A. \& SYMONDSON W.O.C. 1999b: Dynamics of the predatory arthropod community in Spanish olive groves. Agr. Forest Entomol. 1: 219-228.

NARANJO S.E. \& Hagler J.R. 2001: Toward the quantification of predation with gut immunoassays: a new approach integrating functional response behaviour. Biol. Control 20: 175-189.

Oliveros J., García E., Ortíz A., Quesada A. \& Sanchez A. 2003: Optimización de los tratamientos contra Euzophera pingüis (Haworth) (Lepidoptera: Pyralidae) apoyada en la monitorización con feromona sexual. Actas III Congr. Nac. Entomol. Apl. Avila, Spain, p. 208.

OrTiz A. 1996: Semioquímicos del lepidóptero Euzophera pingüis (Haw.). $\mathrm{PhD}$ thesis, Jaén University, Spain, 160 pp.

Rodríguez E. \& CAMpos M. 2004: El Agusanado del olivo (Euzophera pingüis [Haw.]). Vida Rural 156: 50-52.

SANChez A. \& Ortíz A. 2004: La problemática del pirálido del olivo Euzophera pingüis Haworth (I). Phytoma 159: 14-20.

Sunderland K.D. 1996: Progress in quantifying predation using antibody techniques. In Symondson W.O.C. \& Liddell J.E. (eds): The Ecology of Agricultural Pests: Biochemical Approaches. Chapman \& Hall, London, pp. 419-456.

SunDERLAND K.D. \& SutTon S.L. 1980: A serological study of arthropod predation on woodlice in a dune grassland ecosystem. J. Anim. Ecol. 49: 987-1004.

Sunderland K.D., Crook N.E., Stacey D.L. \& Fuller B.J. 1987: A study of feeding by polyphagous predators on cereal aphids using ELISA and gut dissection. J. Appl. Ecol. 24: 907-933.

Symondson W.O.C. \& Liddell J.E. 1993a: The development and characterization of an anti-haemolymph antiserum for the detection of mollusc remains within carabid beetles. Biocontr. Sci. Techn. 3: 261-275.

Symondson W.O.C. \& Liddell J.E. 1993b: Differential antigen decay rates during digestion of molluscan prey by carabid predators. Entomol. Exp. Appl. 69: 277-287.

Symondson W.O.C., Glen D.M., Wiltshire C.W., Langdon C.J. \& LidDELl J.E. 1996: Effects of cultivation techniques and methods of straw disposal on predation by Pterostichus melanarius (Coleoptera: Carabidae) upon slugs (Gastropoda: Pulmonata) in arable field. J. Appl. Ecol. 33: 741-753.

Received November 18, 2004; revised and accepted March 7, 2005 